УДК 330.322 .01

Скоробогатова Н.С.

канд. економ. наук, доцент

Начіональний технічний університет України «КПІ»

\title{
ДОСЛІДЖЕННЯ СУТНОСТІ ІНВЕСТИЦІЙ ТА ІНВЕСТИЦІЙНОЇ ДІЯЛЬНОСТІ
}

\section{ИССЛЕДОВАНИЕ СУЩНОСТИ ИНВЕСТИЦИЙ И ИНВЕСТИЦИОННОЙ ДЕЯТЕЛЬНОСТИ}

\section{RESEARCH OF THE INVESTMENT AND INVESTING ACTIVITIES}

Досліджено теоретичні підходи до трактування сутності економічних категорій «інвестииії», «інвестиційна діяльність», визначено конщептуальні відмінності щодо тлумачення зазначених категорій відповідно до теорій різних економічних шкіл та вітчизняної нормативно-правової бази. Запропоновано узагальнену класифікацію інвестицій, яка включає такі ознаки: напрям інвестування, об'єкти, суб'єкти, призначення, термін, мета, форма власності тощо. Доведено, що інвестиції включають у себе всі вкладення в оборотні та необоротні активи підприємства та мають відображатися у всіх формах фінансової звітності. Встановлено, щуо фінансова звітність вітчизняних комериійних підприємств містить інформацію про інвестиційну діяльність, яка не відповідає економічній сутності даної економічної категорії. Запропоновано визначення інвестииій та інвестищійної діяльності відповідно на макро- та мікроекономічному рівні, щзо враховує особливості учасників інвестиційного процесу, тривалості здійснення інвестицій та їх мети.

Ключові слова: інвестиції, інвестиційна діяльність, баланс, звіт про фінансові результати, звіт про рух грошових коштів, фінансовий облік.

Исследованы теоретические подходы к трактовке сущности экономических категорий «инвестиции», «инвестиционная деятельность», определены концептуальные различия в толковании указанных категорий в соответствии с теорияли различных экономических школ и отечественной нормативно-правовой базой. Предложена обобщенная классификация инвестищий, которая включает следующие признаки: направление инвестирования, объекты, субъекты, назначение, срок, цель, форма собственности и тому подобное. Доказано, что инвестиции включают в себя все вложения в оборотные и необоротные активы предприятия и должны отражаться во всех формах финансовой отчетности. Установлено, что финансовая отчетность отечественных коммерческих предприятий содержит информацию об инвестиционной деятельности, которая не соответствует экономической сущности данной экономической категории. Предложено определение инвестищий и инвестиционной деятельности соответственно на макро- и микроэкономическом уровне, учитывающее особенности участников инвестищионного процесса, продолжсительность осуществления инвестиций и их изели.

Ключевые слова: инвестиции, инвестиционная деятельность, баланс, отчет о финансовых результатах, отчет о движении денежных средств, финансовый учет. 
Theoretical approaches to the interpretation of the essence of an economic categories of "investment", "investment activity". Defined conceptual differences in the interpretation of these categories in accordance with the theories of the different schools and domestic legal frameworks. Article generalizes classification of the investment, which includes the following features: the direction of investment objects, subjects, appointment, term, purpose, ownership, and the like. It is proved that the investments include all investments in current and non-current assets of the enterprise. They should be reflected in all forms of financial statements. It was found that the financial statements of domestic commercial enterprises provides information on investment activity, which does not correspond to the economic essence of the economic category. A definition of investments and investment activity at the macroeconomic and microeconomic level, considering features of the participants of the investment process, the duration of the investment and its purpose.

Keywords: investing, investment, balance sheet, income statement, statement of cash flows, financial accounting.

Вступ. Інвестиції $€$ невід’ємною частиною діяльності будь-якої юридичної чи фізичної особи. У широкому розумінні інвестиції - це будь-які вкладення задля досягнення мети інвестора - як матеріальної у вигляді прибутку, так і нематеріальної у вигляді соціального ефекту. Відповідно, 3 інвестиціями пов'язана інвестиційна діяльність. Дослідженню питань сутності та ефективності інвестицій присвячено праці А. І. Бланка [15], В. В. Бочарова, Б. В. Губського, Я. І. Єлейка, І. В. Ліпсица, П. Р. Кругмана, А. А. Пересади, В. Г. Федоренка, Б. М. Щукіна, А. Александера, Дж. Бейлі, Г. Макміллана, В. Шарпа [11], Дж. Ван Хорна, Дж. Гітмана та інших. Завдяки роботам науковців розкрито та досліджено значну кількість теоретичних підходів, що стали основою для грунтовного розуміння сутності інвестицій та оцінки їх ефективності. Проте вважаємо, що залишаються недостатньо дослідженими та у певних моментах протиречними питання визначення сутності інвестиційної діяльності з врахуванням особливостей іiі реалізації у різних масштабах. Зокрема, існує багато протиріч у трактуванні даного терміну як у літературних джерелах, так і в нормативно-правовій базі.

Постановка завдання. Метою роботи $\epsilon$ визначення сутнісних характеристик категорії «інвестиційна діяльність» та формулювання визначення даної економічної категорії з врахуванням масштабів та суб'єктів, задіяних при iї реалізації. Для досягнення поставленої мети було визначено такі завдання:

- аналіз теоретичних підходів до визначення сутності категорій «інвестиції», «інвестиційна діяльність», «інвестиційний процес» та надання іiі грунтовного трактування з врахуванням сучасних умов господарювання;

- визначення місця інвестиційної діяльності підприємства в системі видів його діяльності;

- надання практичних рекомендацій щодо ідентифікації інвестиційної діяльності та ії результатів. 
Методологія. Теоретико-методологічну основу дослідження становлять наукові праці, методичні розробки провідних вітчизняних і зарубіжних учених та нормативно-правова база в області інвестування. Вирішення наукових завдань здійснювалось 3 використанням критичного аналізу, наукового узагальнення та систематизації при дослідженні сутності категорії «інвестиційна діяльність». Результати дослідження, висновки та рекомендації обгрунтовано шляхом комплексного підходу.

Результати дослідження. У широкому розумінні категорія «інвестиції» (від лат. investio - одягаю) означає вкладення капіталу 3 метою його наступного збільшення. Зазначений підхід до тлумачення «інвестицій» $\epsilon$ основним у закордонній та сучасній вітчизняній методології $[1,2]$. Проте слід зазначити, що закордонні науковці певний період часу більший акцент при визначенні інвестицій робили саме на фінансових інвестиціях, тобто вкладенні у цінні папери. Таку ситуацію можна пояснити більшим розвитком ринку фінансових інструментів у міжнародній практиці. Що стосується вітчизняних науковців, то за радянські часи термін інвестиції взагалі не використовувався. Замість нього широко поширеним було використання терміну «капітальні вкладення», під яким розумілися витрати підприємств на створення нових, розширення, реконструкцію, технічне переоснащення діючих підприємств та оновлення основних фондів, впровадження нової техніки у виробничих галузях народного господарства, будівництво об'єктів усіх галузей соціальної сфери та виконання проектних i геологорозвідувальних робіт. Таким чином, акцент робився на реальні інвестиції. Аналіз літературних джерел дозволив узагальнити класифікацію інвестицій (рис. 1). 


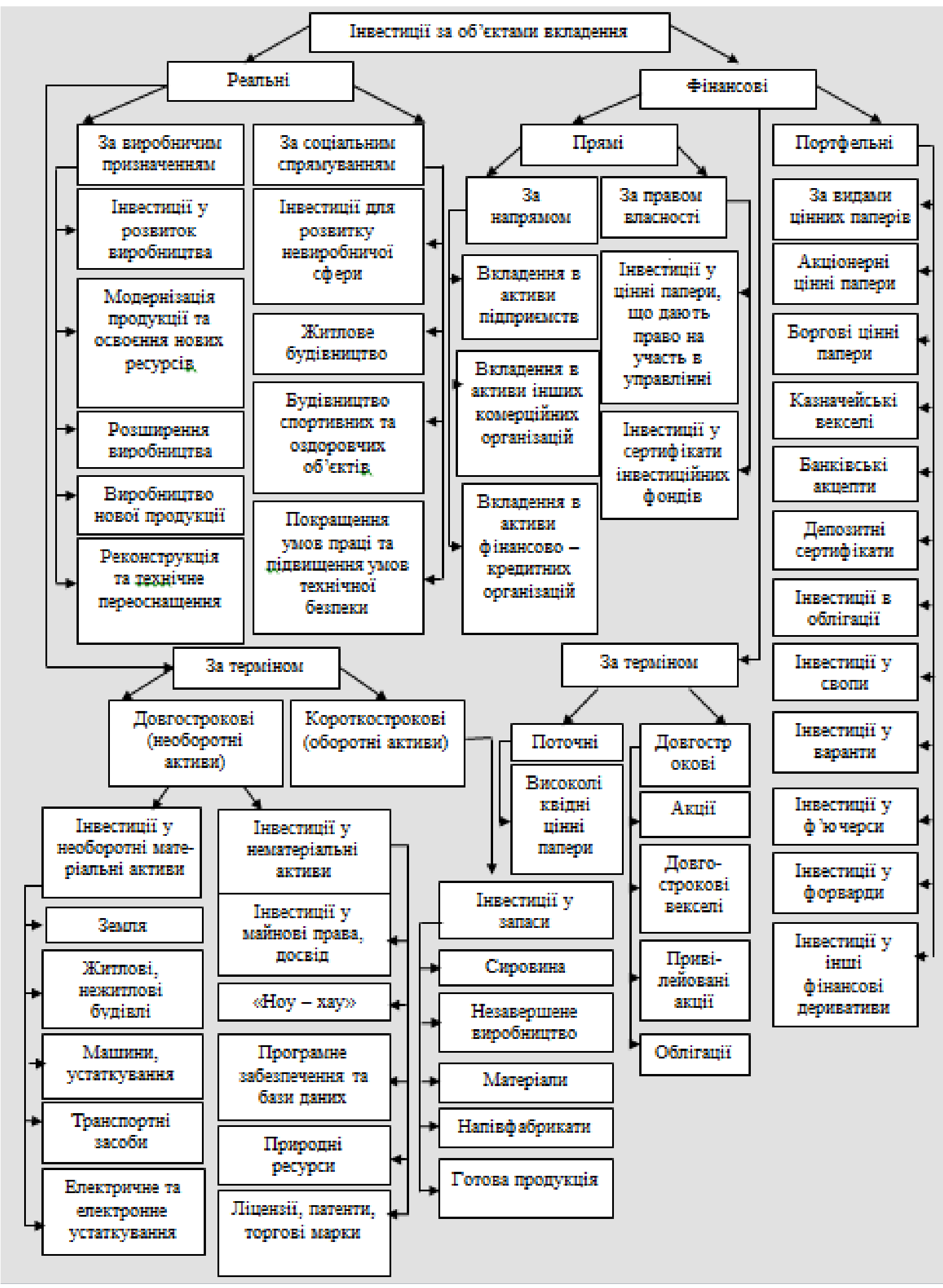

Рис. 1. Класифікація інвестиції

Узагальнено автором за [11, с. 540; 5, с. 76-77] 
Відповідно до юридичного підходу, наведеного у Законі України «Про інвестиційну діяльність», інвестиціями $є$ всі види майнових та інтелектуальних цінностей, що вкладаються в об'єкти підприємницької та інших видів діяльності, в результаті якої створюється прибуток (доход) або досягається соціальний ефект. Основними розмежувальними критеріями між різними тлумаченнями інвестицій виступають об'єкт інвестування та тривалість зв'язування капіталу. Вважаємо доцільним виділити макро- та мікроекономічний підхід до тлумачення інвестицій.

Згідно 3 макроекономічним підходом, представниками якого $\epsilon$ Кейнс Дж. М., Макконелл К.Л., Брю С.Л., Менкью Н.Г., інвестиції визначаються як «приріст будь-яких матеріальних цінностей - усіх витрат, що безпосередньо сприяють зростанню загальної величини капіталу в економічній системі». Відповідно до мікроекономічного підходу, інвестиції розуміються як «вкладення капіталу (тобто грошових коштів) в капітальні вкладення та оборотні активи» (Борщ Л.М.[1], Андрєєв Д.М., Бочаров В.В., Гітман Л.Дж., Джонк М.Д., Хелферт Е., Ван Хорн Дж. К., Шарп У.[11], Александер Г., Бейлі Дж.). На рівні підприємства інвестиції відображаються у такій формі фінансової звітності, як Баланс (звіт про фінансовий стан). В активі відображаються інвестиції, а в пасиві - джерела їх фінансування (рис. 2).

\begin{tabular}{|c|c|c|c|}
\hline \multicolumn{2}{|c|}{ Актив } & \multicolumn{2}{|l|}{ Пасив } \\
\hline $\begin{array}{l}\text { 1. Необоротні } \\
\text { активи }\end{array}$ & $\begin{array}{c}\text { Довгострокові } \\
\text { реальні та фінансові } \\
\text { інвестиції }\end{array}$ & 1. Власний капітал & $\begin{array}{c}\text { Власні та } \\
\text { залучені } \\
\text { джерела }\end{array}$ \\
\hline $\begin{array}{l}\text { 2. Оборотні } \\
\text { активи }\end{array}$ & & $\begin{array}{l}\text { 2. Довгострокові } \\
\text { зобов'язання і забезпечення }\end{array}$ & \\
\hline 3. Необоротні & & $\begin{array}{l}\text { 3. Поточні зобов'язання і } \\
\text { забезпечення }\end{array}$ & \\
\hline $\begin{array}{l}\text { активи, } \\
\text { утримувані для } \\
\text { продажу, та } \\
\text { групи вибуття }\end{array}$ & $\begin{array}{l}\text { Поточні реальні та } \\
\text { фінансові інвестиції }\end{array}$ & $\begin{array}{l}\text { 4. Зобов’язання, пов’язані з } \\
\text { необоротними активами, } \\
\text { утримуваними для } \\
\text { продажу, та групами } \\
\text { вибуття }\end{array}$ & $\begin{array}{l}\text { Запозичені } \\
\text { джерела }\end{array}$ \\
\hline
\end{tabular}

Рис. 2. Відображення інвестицій та джерел їх фінансування в Балансі

Залежно від тривалості використання інвестиції можуть відображатися не в Балансі, а у Звіті про фінансові результати (Звіт про сукупний дохід): витрати на поточне виробництво, збутові, адміністративні та інші витрати.

В залежності від того, де відображаються інвестиції, тривалість зв'язування капіталу у вигляді інвестицій може бути довготривалою (необоротні активи) або короткотривалою (оборотні активи та витрати на управління підприємством). Суть інвестування, 3 точки зору інвестора 
(власника капіталу), полягає у відмові отримання прибутку «сьогодні» для отримання його «завтра». Відповідно, для прийняття рішення про довгострокове вкладення капіталу необхідно володіти інформацією, яка підтверджує два основних припущення:

- вкладені кошти мають бути повністю відшкодовані;

- прибуток, отриманий в результаті даної операції, має бути достатньо великим, щоб компенсувати тимчасову відмову від використання коштів, а також ризику, що виникає через невизначеність кінцевого результату.

Інвестиції підприємства відображаються і у Звіті про рух грошових коштів, який деталізує рух грошових коштів від трьох видів діяльності підприємства: операційної, інвестиційної, фінансової. Проте вважаємо, що наведена інформації про інвестиційну діяльність підприємства у даному звіті $\epsilon$ значно звуженою, маючи на увазі сутність інвестицій (рис. 3).

\begin{tabular}{lc} 
Надходження від реалізації: & \\
- фінансових інвестицій & + \\
Н необоротних активів & + \\
Надходження від отриманих: & \\
в дидсотків & + \\
Надходжендів & + \\
Інші надходження & + \\
Витрачання на придбання: & + \\
- фінансових інвестицій & - \\
- необоротних активів & - \\
Виплати за деривативами & - \\
Інші платежі & - \\
\hline Чистий рух коштів від інвестиційної діяльності & $\sum$
\end{tabular}

Рис. 3. Схема руху грошових коштів від інвестиційної діяльності підприємства, відповідно [8]

Аналіз літературних джерел та нормативно-правової бази свідчить про неузгодженість щодо визначення економічної категорії «інвестиційна діяльність» (таблиця). Більшість вітчизняних науковців надають тлумачення терміну аналогічне тому, що $\epsilon$ в Законі України «Про інвестиційну діяльність»: «інвестиційною діяльністю $є$ сукупність практичних дій громадян, юридичних осіб і держави щодо реалізації інвестицій». Аналізуючи наведене визначення залишається незрозумілим сутність процесу «реалізації інвестицій». Водночас, у Національному положенні (стандарті) бухгалтерського обліку 1 «Загальні вимоги до фінансової звітності» надано наступне визначення інвестиційної діяльності: «придбання та реалізація тих необоротних активів, а також тих фінансових інвестицій, які не є складовою частиною еквівалентів грошових коштів». 
Деякі підходи до визначення інвестиційної діяльності

\begin{tabular}{|c|c|}
\hline Джерело (автор) & Визначення \\
\hline Майорова Т.В. [6] & $\begin{array}{l}\text { Інвестиційна діяльність (інвестування) - це сукупність практичних } \\
\text { дій громадян, юридичних осіб та держави щодо реалізації } \\
\text { інвестицій. }\end{array}$ \\
\hline $\begin{array}{l}\text { Гриньова В.М., } \\
\text { Коюда В.О., } \\
\text { Лепейко Т. І., } \\
\text { Коюда О.П. [4] }\end{array}$ & $\begin{array}{l}\text { Інвестиційна діяльність - це сукупність практичних дій } \\
\text { фізичних, юридичних осіб і держави щодо реалізації інвестицій. } \\
\text { Інвестиційна діяльність - це складова економічного управління } \\
\text { діяльності підприємства, що потребує визначення організаційно- } \\
\text { економічних методів і форм управління всіма стадіями } \\
\text { інвестиційних процесів на рівні підприємства - регіону — галузі } \\
\text { - національного господарства в цілому. }\end{array}$ \\
\hline Мойсеєнко І.П. [7] & $\begin{array}{l}\text { Інвестиційна діяльність підприємства - це об'єктивний процес, } \\
\text { що має свою логіку і розвивається відповідно до властивих йому } \\
\text { закономірностей, відіграє важллву роль у господарській } \\
\text { діяльності підприємства, оскільки за своєю економічною } \\
\text { природою інвестиції являють собою відмову від сьогочасного } \\
\text { споживання заради одержання прибутків у майбутньому. }\end{array}$ \\
\hline $\begin{array}{l}\text { Закон України «Про } \\
\text { інвестиційну } \\
\text { діяльність» }[10]\end{array}$ & $\begin{array}{l}\text { Інвестиційною діяльністю є сукупність практичних дій } \\
\text { громадян, юридичних осіб і держави щодо реалізації інвестицій. }\end{array}$ \\
\hline Щукін Б. М. [12,с.23] & $\begin{array}{l}\text { Інвестиційна діяльність представляє інвестиційний процес в } \\
\text { реальних умовах, з акцентом на організаційні засади його } \\
\text { реалізації та управління цим процесом. Як правило, інвестиційна } \\
\text { діяльність розглядається стосовно конкретного інвестиційного } \\
\text { проекту та підприємства (юридичної особи), що здійснює } \\
\text { інвестиційний процес. }\end{array}$ \\
\hline Поєдинок В. В. [9] & $\begin{array}{l}\text { Інвестиційна діяльність - це сукупність дій господарського та } \\
\text { управлінсько-господарського характеру, які вчиняються } \\
\text { суб’єктами господарювання щодо підготовки до вкладення } \\
\text { інвестицій, безпосереднього вкладення інвестицій (інвестування) } \\
\text { та господарського використання вкладених інвестицій. }\end{array}$ \\
\hline $\begin{array}{l}\text { Витун С.C., } \\
\text { Чигрина А.I. [3] }\end{array}$ & $\begin{array}{l}\text { Iнвестиційна діяльність представляє собою частину господарської } \\
\text { діяльності підприємства щодо цільового формування та } \\
\text { розпорядження власними та позичковими джерелами фінансових } \\
\text { ресурсів, а також амортизацією, що забезпечують його розширене } \\
\text { відтворення. }\end{array}$ \\
\hline
\end{tabular}

Проте поточні фінансові та реальні інвестиції залишаються поза цією формою фінансової звітності. Тобто акцент робиться на придбанні та реалізації саме необоротних активів та фінансових інвестицій, тоді як оборотні активи так само є об'єктом інвестування (рис. 1). Таким чином, нормативно-правова бухгалтерського обліку значно звужує межі категорії «інвестиції», включаючи до них лише довгострокові реальні та фінансові 
інвестиції, що суперечить самій сутності даної економічної категорії. Національним стандартом (положенням) бухгалтерського обліку 1 визначено такі види діяльності:

- звичайна діяльність - будь-яка основна діяльність підприємства, а також операції, що її забезпечують або виникають внаслідок іiї проведення;

- основна діяльність - операції, пов'язані з виробництвом або реалізацією продукції (товарів, робіт, послуг), що є головною метою створення підприємства і забезпечують основну частку його доходу;

- операційна діяльність - основна діяльність підприємства, а також інші види діяльності, які не є інвестиційною чи фінансовою діяльністю;

- фінансова діяльність - діяльність, яка призводить до змін розміру $\mathrm{i}$ складу власного та позикового капіталів підприємства;

- інвестиційна діяльність - придбання та реалізація тих необоротних активів, а також тих фінансових інвестицій, які не є складовою частиною еквівалентів грошових коштів.

За такої класифікації видів діяльності підприємства інвестиційна діяльність, як вже зазначалося, обмежена лише довгостроковими інвестиціями, а поточні інвестиції відносяться до операційної діяльності, що суперечить сутності інвестицій. Зазначена суперечність між визначеннями інвестиційної діяльності може бути пояснена тим, що кожне визначення певного терміну у законодавчих документах надається для певних цілей застосування. У Господарському кодексі України надається визначення господарської діяльності, яка за своїм змістом стосується основної діяльності суб'єктів господарювання, яка пов'язана 3 виробництвом або реалізацією продукції (товарів, робіт, послуг), що $\epsilon$ головною метою створення відповідного суб'єкта та забезпечує основну частку його доходу. Для професійних інвесторів інвестиційна діяльність є основною діяльністю, тому це визначення для них цілком доцільне. Для решти суб'єктів господарської діяльності інвестиційна діяльність спрямована на здійснення, поширення та розвиток основної діяльності.

Класифікація видів господарської діяльності (КВЕД) заснована на принципі класифікації за галузями, зокрема у самому документі зазначено, що об'єктами класифікації є види економічної діяльності юридичних осіб, відокремлених підрозділів юридичних осіб і фізичних осіб-підприємців, що на вищих рівнях класифікації групують галузі. Проте інвестиційна діяльність здійснюється не за галузевим принципом, як вище доведено, іiі здійснює будьякий господарюючий суб'єкт, як за широким, так і за більш вузьким тлумаченням. Водночас, інвестиційна діяльність пронизую всі галузі виробництва. Таким чином, питання однозначного тлумачення інвестиційної діяльності підприємства на законодавчому рівні залишається не визначеним. 
Оскільки аналіз результатів діяльності підприємства здійснюється на підставі даних фінансової звітності, то вважаємо некоректним оцінку ефективності інвестиційної діяльності визначати, виходячи 3 визначення даного виду діяльності на підставі норм стандартів бухгалтерського обліку. Неузгодженість законодавчого визначення, форм фінансової звітності та економічної сутності інвестиційної діяльності призводить до ускладнення та в деяких випадках неможливості моніторингу інвестиційних проектів, що реалізуються на діючих підприємствах.

Таким чином, вважаємо доцільним при аналізі інвестиційної діяльності виходити 3 розподілу даного виду діяльності на два рівні - макро- та мікроекономічний. Відповідно до макроекономічного підходу, під інвестиційною діяльністю слід розуміти сукупність практичних дій фізичних, юридичних осіб і держави щодо здійснення інвестицій. Згідно 3 мікроекономічним підходом, інвестиційна діяльність - це сукупність дій суб'єктів господарювання, спрямованих на підготовку, вкладення та використання інвестицій. Окрім того, вважаємо необхідним привести у відповідність визначення економічної категорії «інвестиційна діяльність» та елементи фінансової звітності підприємств, що дозволить і інвесторам, i власникам, і потенційним партнерам, і державним органам влади знайти порозуміння, аналізуючи результати того чи іншого підприємства.

Висновки. В результаті проведеного дослідження встановлено, що існують різні підходи до тлумачення інвестицій, що підтверджують концепції вітчизняних та закордонних економічних шкіл. Доведено, що інвестиційна діяльність відображається у всіх формах фінансової звітності підприємства. Неузгодженість вітчизняного законодавства у сфері регулювання інвестиційної діяльності та складання фінансової звітності призводить до перекручування інформації у фінансових звітах та непорозуміння iï потенційними партнерами, інвесторами та іншими зацікавленими особами.

Науковою новизною є запропоноване визначення інвестицій та інвестиційної діяльності, відповідно, на двох рівнях: макро- та мікроекономічному. Зокрема, відповідно до макроекономічного підходу, під інвестиціями слід розуміти здійснення витрат будь-яких цінностей, що призводять до зростання вартості капіталу в економічній системі. Відповідно до мікроекономічного підходу, інвестиції - це вкладення капіталу у будь-які об'єкти з метою створення додаткової вартості. Аналогічно, відповідно до макроекономічного підходу, під інвестиційною діяльністю слід розуміти сукупність практичних дій фізичних, юридичних осіб і держави щодо здійснення інвестицій. Згідно 3 мікроекономічним підходом, інвестиційна діяльність - це сукупність дій суб'єктів господарювання, спрямованих на підготовку, вкладення та використання інвестицій. 
Водночас подальшого дослідження потребує розробка методологічної бази щодо оцінювання результативності зв'язку використання оборотних i необоротних активів підприємства та ефективністю інвестиційних рішень.

\section{Література:}

1. Бланк А. И. Основы инвестиционного менеджмента / А. И. Бланк. - К.: Ника-Центр, Эльга-Н, 2001. - 672 с.

2. Борщ Л. М. Інвестування: теорія і практика / Л. М. Борщ. - К. : Знання, 2005. -470 с.

3. Витун С. Е. Финансы предприятия отрасли : пособие / С. Е. Витун, А. И. Чигрина. Гродно: ГрГУ им. Я. Купалы, 2009. - 213 с.

4. Гриньова В.М. Інвестування / В. М. Гриньова, В. О. Коюда, Т. І. Лепейко, О. П. Коюда. - К.: Знання, 2008. - 456 с.

5. Корпан О. С. Сучасні підходи до класифікації інвестицій: проблеми та перспективи / О. С. Корпан [Електронний ресурс] // Механізми управління діяльністю вітчизняних підприємств за умов розвитку інтеграційних процесів. Вісник Хмельницького національного університету. Науковий журнал, 2009 р. - Режим доступу: http://www.nbuv.gov.ua/portal/natural/Vchnu/Ekon/2009_6_2/075-079.pdf.

6. Майорова Т.В. Інвестиційна діяльність: Навчальний посібник / Т В Майорова. - К.: Центр навчальної літератури, 2004. - 376 с.

7. Мойсеєнко І. П. Інвестування: Навч. посіб. / Мойсеєнко І.П. - К.: Знання, 2006. $490 \mathrm{c}$.

8. Національне положення (стандарт) бухгалтерського обліку 1 «Загальні вимоги до фінансової звітності», затверджене Наказом МФУ 07.02.2013 № 73 [Електронний peсурс]. - Режим доступу: http://zakon3.rada.gov.ua/laws/

9. Поєдинок В. В. Інвестиційна діяльність як вид господарської діяльності / В. В. Поєдинок // Господарське право та господарський процес. - 6-2/2013. - С.131 - 135 .

10. Про інвестиційну діяльність : закон України від 18.09.1991p. № 1560-XII [Електронний ресурс]. - Режим доступу: http://zakon0.rada.gov.ua/laws

11. Шарп У.Ф. Инвестиции: [учебное пособие] / У.Ф. Шарп; пер с англ. - М.: ИНФРА-М, 1998. $-1028 \mathrm{c}$.

12. Щукін Б. М. Інвестування: курс лекцій / Б. М. Щукін. - К.: МАУП, 2004. - 216 с. : іл. - Бібліогр. с. 214 